\title{
The Effect of a Moodle-Based LMS in "Article Writing for Journal" Subject for Post Graduate Students
}

\author{
Tomo $^{1}$, J. Priyanto Widodo ${ }^{2}$, Shierly Novalita Yappi ${ }^{3}$ \\ ${ }^{1,2,3}$ STKIP PGRI Sidoarjo \\ tomosumenep@gmail.com,prowidodo18@gmail.com,snovalita@gmail.com
}

\begin{abstract}
The goal of this study was to find out how effective a Moodle-based Learning Management Systems (LMS) work for post-graduate students at STKIP PGRI Sidoarjo who are taking a "Article Writing for Journal" subject. To reach that goal, we used total sampling in an experimental method with a pre-test and post-test design for two groups. The students who took part in the study were post-graduate students in the third semester of the 2020/2021 academic year. There were two groups, and each group had 12 students in it. The researchers gave the students a pre-test and a post-test about "Article Writing" as the products to get the data. Then, the researcher used a t-test to see if the model had an effect on the data. The students who were taught using a Blended method that used LMS Moodle and those who were only taught in a virtual class were both better at writing than those who were only taught in a virtual class. SPSS version 26 was used to look at data from the pre- and post-tests. The Manova test and the Normalized gain were used to look at the data (N-gain). Manova's results showed that there was a significant difference in how well students learned to write in English. This means that the treatment that included Moodle-based e-learning and only face-to-face classes has had a big impact on students' English writing skills.
\end{abstract}

Keywords

Moodle; LMS; article writing for journal; post-graduate

\section{Introduction}

In today's world, technology has advanced to the point where it affects nearly every aspect of daily life, and education is no exception. This year's Pandemic Covid-19 has seen an increase in educational institutions integrating technology and the internet into classroom language instruction. Furthermore, it is true that in recent times, curricula have been delivered online rather than on local desktops. Virtual Learning Environments (VLEs) and Course Management Systems (CMSs) have been adopted by nearly all colleges and universities as teaching aids to their traditional courses, which is often referred to as a "blended" or "hybrid" system (Robb, 2004). Web-based technologies (such as interactive learning, live virtual classroom environments, streaming media) are used in a blended learning approach in order to accomplish the goal of teaching. This method incorporates a variety of teaching styles, including constructivism, cognitivism, and behaviourism. For the most effective training results, it's best to use a combination of teaching methods and traditional face-to-face teaching (Sharma \& Barret, 2010).

Developing a blended learning model necessitated additional effort. Learning media are required to facilitate the organization of online learning activities. Additionally, if lecturers use a blended learning model, the teaching media should facilitate a variety of online English learning activities. Among the numerous types of educational media, there is one that facilitates a variety of online learning activities: the Learning Management System (LMS). A learning management system (LMS) is a piece of software that is used to 
facilitate online learning activities and is connected to the internet. Until now, there have been numerous LMS products available for selection and use. By delivering information to learners as quickly as possible, blended learning can help save time, effort, and money. It enables the management and control of the educational process, the measurement and evaluation of learners' performance, and the overall level of educational attainment to be increased while maintaining an attractive learning environment (Shomali, 2007). In the development of the world of education, especially after the rolling reforms, new phenomena have arisen in educational institutions, which are schools that use the term Integrated Islamic Schools (Titik, 2010: 42). The school is essentially aimed at helping parents teach good habits and add good character, also given education for life in society that is difficult given at home. Thus, education in schools is actually part of education in the family, which is also a continuation of education in the family (Daulay in Ayuningsih, W. et al. 2020).

Circular Number 4 of 2020 was issued by the Minister of Education and Culture as a response to the declaration of Covid-19 as a global pandemic. This circular primarily discusses the implementation of Education Policy in light of Covid-19 Outbreak (Kemdikbud, 2020). As a result, the government has implemented programs for students to learn at home or via distance education. Face-to-face instruction has given way to a computer-based learning environment. It's all done online. There is an online learning system implemented at every level of education, from elementary school to college and beyond. An online learning system has been implemented at STKIP PGRI Sidoarjo. All departments have accepted online education. Master of English Education (MPBI) is one of the departments which uses online learning in all courses at STKIP PGRI Sidoarjo. Due to its integration with university's Learning Management System (LMS), Moodle has been applied in online classroom.

Moodle is a popular learning management system for transferring language teaching and learning. Moodle is an open-source, licence-free computing application that includes an e-learning component. Moodle has received widespread attention in the field of ESL and EFL (Elhawwa, 2017). Moodle has the potential to be a comprehensive and adequate platform for integration in higher education settings with high expectations for teaching where numerous educators and professionals prefer and utilize Moodle in their second and foreign language classes (Eka, 2021). Moodle's set of features includes the following: (1) course content management, (2) synchronous and asynchronous communication, (3) content uploading, (4) peer assessment, (6) student administration, (7) grade collection and organization, (8) online questionnaires, (9) online quizzes, and (10) tracking tools.

Post-graduate students at STKIP PGRI Sidoarjo take a course called "Article Writing for Journal”. The Moodle-based LMS of SIDALACE (STKIP PGRI Sidoarjo Learning Space) was used for all of the university's academic endeavours. One of the goals of this subject is to teach students how to write a scientific article that is published in a reputable journal at least in SINTA 3 (Science and Technology Index 3). Having the ability to write is critical since writing is an effective means of expressing oneself as well. People can freely express their thoughts and feelings through the use of their own language when they write. It demonstrates that writing is a 'process of thought' (Rukayah, 2014). Writing is a chance and allows students to express their thoughts and views on a variety of topics (Sanjaya, 2011). Using good writing, students can convey their thoughts to others so that they understand what they are saying. It was a common belief among students that writing is essential for expressing one's thoughts in terms of ideas, inspirations, creativity, and feelings. All students must have excellent writing abilities if they are to succeed in school and land a job after graduation (Durga \& Rao, 2018). 
Post-graduate students at STKIP PGRI Sidoarjo had a problem with writing especially for scientific writing, according to preliminary observations by the researchers. Some students struggled with scientific writing because they didn't know what to write about or how to write for a good article for journal. It can also create a learning environment that was previously overlooked. It is still traditional to teach English as a second language in all subjects, with the emphasis on developing general English proficiency rather than language proficiency for a specific purpose. It's still not meeting students' needs because the material provided is passive English rather than active English. As a result, students lose interest in subjects like "Article Writing for Journal", which teaches scientific writing, and their performance suffers as a result. Developing writing skills can be hindered and learning outcomes aren't as good as they could be.

Roberston (2008) discussed how (CMS) technologies can be integrated into an existing EFL writing curriculum using the author's constructivist definition of a communal learner and communicator as the starting point for his article. With the help of specific examples, the author hopes to demonstrate specific Moodle (CMS) features that support activities and approaches that are inherent in the writing class of the "process approach". He also claimed that by incorporating Moodle's (CMS) technologies into the writing course, instructors would benefit in the areas of management, communication, and evaluation, among other things. Due to a shared interest in the use of Moodle as an efficient and fruitful online platform to develop students' writing skills, Wu (2008) conducted a study in which he investigated the application of Moodle to an EFL undergraduate writing course in Taiwan's context. It has been demonstrated that Moodle is a user-friendly content management system (CMS), as he concluded, and that it can easily assist English writing instructors in organizing their teaching materials, improving all modes of communication and, if necessary, retrieving their records of student contact. This research had similar discussion which investigated Moodle in writing class, but the difference between this research and the previous studies were on the effectiveness Moodle on students' achievement in "Article Writing for Journal" subject for post-graduate students at STKIP PGRI Sidoarjo.

\section{Review of Literature}

\subsection{Moodle}

Moodle, according to Martin Dougiamas (1998), is the first Course Management System (CMS) that he has developed. Moodle is an open-source CMS that is currently used by universities, educational institutions, K-13 schools, businesses, and individual instructors who wish to manage their courses through the use of web technology (Cole, 2005). Moodle is a website-based application package that includes support for the PHP and MySQL programming languages, and it is available for free (open source). To put it another way, Moodle is capable of utilizing and adapting to the needs of the user. The Moodle installation package can be obtained from the official Moodle website at http://moodle.org. Asynchronous communication (chats) and synchronous communication (discussion forums) mechanisms are used on this platform to facilitate the exchange of information among users who are geographically dispersed (Costa, Alvelos, \& Teixeira, 2012). In terms of adaptability and the implementation of new features, Moodle is a reasonably compatible tool. It is possible to add processes to the system without making any changes to the core.

Moodle assists teachers or educators through the use of its features, which include, but are not limited to, a quiz, workshop, forum, assignment, and questionnaire, among 
others (Mirabolghasemi, Iahad, \& Qomaruddin, 2014). It is possible to have some assignments and quiz types that are automatically graded, which makes the learning process more efficient. As a result, it saves time for educators in grading students' work, and it assists students in improving their learning by providing immediate feedback on their work (Costa, 2015). Another aspect of Moodle that is beneficial to the educational system is the fact that learning materials are centred on the learner. Students have access to all of the learning materials they require at any time and from any location, which Encourages them to continue learning and reviewing their progress at their own pace, regardless of where they are.

In the same way that educators must become familiar with the web-based platform (Cole, 2005), learners must become familiar with the platform as well. Learners must be self-aware of the importance of education in their own lives in order to benefit from it. Moodle is a tool that will assist students in achieving their learning objectives; however, it is the students' responsibility to complete the learning and complete the tasks that have been assigned to them in order to assist them in learning about the subject. As a result, students will be required to employ certain abilities such as time management, self-drive or motivation, critical thinking, and basic information technology skills (Ahmadi, 2018).

\subsection{Writing Skill}

In writing, the writer must demonstrate control over a number of variables at the same time, which is a highly complex cognitive activity. Control of the contents, the format, the sentence structure, the vocabulary, the spelling, and the letter formation are all examples of sentence-level control. Apart from the ability to write a sentence, the writer must be able to structure and integrate information into a cohesive and coherent paragraph or text (Linse \& Nunan, 2006). Writing skills, are complex and difficult to teach because they require mastery of not only grammatical and rhetorical devices, but also conceptual and judgmental elements.

Furthermore, according to Brown (2007), writing is a method of arriving at a conclusion about something. Putting information into written text is a psychological activity involving the language that is performed by the writer. According to the discussion above, writing is a method of expressing ideas, feelings, and opinions through the use of written text in order to provide readers with information on paper. Ideas, feelings, and opinions are expressed through writing in a written form known as writing. Writing is an extremely important skill for students to have. Furthermore, writing is an excellent means of communication because it is the process of communicating something (content) on paper for others to read (Brown, 2007).

\section{3 "Article Writing for Journal" Subject}

"Article Writing for Journal" is one of the subjects taught at STKIP PGRI Sidoarjo in taking Master of English Education (MPBI) degree. This course has three credits in semester (3 SKS) which is available on the third semester of post-graduate students at STKIP PGRI Sidoarjo. As its goals in this writing subjects, at the end of the semester, students are hoped to master a scientific writing and the writing product will be published on reputable journals at least on SINTA 3 (Science and Technology Index 3). All of the activities in this subject were taught through online learning by using a Moodle platform of Learning Management System (LMS) called SIDALACE.

In "Article Writing for Journal", writing ability can be best defined as the ability to compose texts in a variety of genres that are appropriate for their intended audience and purpose, which is perhaps the most accurate definition. It is difficult, if not impossible, to 
extrapolate generalizations from a single text on a single topic written under time constraints to the broader universe of written communication. Many individual teachers and writing programs have adopted portfolio assessment as a (potentially) more valid approach to writing assessment as a result of this trend (Weigle, 2007). The possibility of assessing writing online is a relatively recent development in the field of writing assessment. At the very least, online writing assessment allows for the creation of tests that are tailored to the levels, purposes, and requirements of test takers, as well as those of future employers, admissions officers, and other stakeholders (Hamp-Lyons, 2002).

\section{Research Method}

In the even semester of the 2020/2021 Academic Year, the researcher conducted this study at STKIP PGRI Sidoarjo, one of the private universities in Sidoarjo. The sample for this study was made up of 24 postgraduate students enrolled in the master of English education (MPBI) Batch 7. The sample was chosen using total-sampling, and they were divided into two groups: the first group consisted of 12 students in an experimental class, and the second group consisted of 12 students in a control class. The experimental group used a blended learning approach, which combined online learning with face-to-face virtual classes and LMS Moodle. The control group, on the other hand, utilized only faceto-face virtual classes. The type of quasi-experimental study depicted in Table. 1 is a two groups pre-test and post-test design.

Table 1. The Two Groups Pre-test and Post-test Design

\begin{tabular}{|l|c|c|c|}
\hline \multicolumn{1}{|c|}{ Class } & Pre-test & Treatment & Post-test \\
\hline Experiment & XE1 & T & XE2 \\
\hline Control & XC1 & O & XC2 \\
\hline
\end{tabular}

Description:

XE1: Pre-test in experimental group

XE2: Post-test in experiment group

$\mathrm{XC1}$ : Pre-test in control group

$\mathrm{XC2}$ : Post-test in control group

T: Treatment using Moodle and face-to-face virtual class

O: Treatment only using face-to-face virtual class

\section{Result and Discussion}

Students' writing abilities in the "Article Writing for Journal" subject were assessed through the administration of tests that included 'Article' writing as the product. A pre-test was administered to both the experimental and control groups to ascertain their baseline writing ability. Then, a post-test was conducted to determine whether the use of the LMS Moodle had an effect on the students' English writing skills. Both test results were validated using the Manova test via SPSS 26, which requires that the data be normally distributed and homogeneous. The normality and homogeneity of the pre-test and post-test data were demonstrated in following tables. 
Table 2. Pre-test and Post-test Data Normality

\begin{tabular}{|c|c|c|c|c|c|c|}
\hline \multicolumn{7}{|c|}{ Pre-test Data } \\
\hline \multirow[b]{2}{*}{ Skill } & \multicolumn{3}{|c|}{ Experiment } & \multicolumn{3}{|c|}{ Control } \\
\hline & $\begin{array}{l}\text { Kolmogorov - } \\
\text { Smirnov }\end{array}$ & Sig & Remark & $\begin{array}{l}\text { Kolmogorov } \\
\text { - Smirnov }\end{array}$ & Sig & Remarks \\
\hline Writing & 1.28 & 0.07 & Normal & 1.36 & 0.06 & Normal \\
\hline \multicolumn{7}{|c|}{ Post-test Data } \\
\hline \multirow[b]{2}{*}{ Skill } & \multicolumn{3}{|c|}{ Experiment } & \multicolumn{3}{|c|}{ Control } \\
\hline & $\begin{array}{l}\text { Kolmogorov - } \\
\text { Smirnov }\end{array}$ & Sig & Remark & $\begin{array}{l}\text { Kolmogorov } \\
\text { - Smirnov }\end{array}$ & Sig & Remarks \\
\hline Writing & 1.21 & 0.11 & Normal & 1.16 & 0.12 & Normal \\
\hline
\end{tabular}

If the significance value is greater than 0.05 or the calculated $\mathrm{z}$ value is greater than 0.05 , the data will be accepted as normal (Kolmogorov Smirnov Z). The data presented above demonstrates that all statistical significance values are greater than 0.05 . All of the data has a normal distribution.

Table 3.Pre-test and Post-test Data Homogeneity

\begin{tabular}{|l|l|c|c|}
\hline \multicolumn{1}{|c|}{ Data } & \multicolumn{1}{|c|}{ Group } & Sig. & Conclusion \\
\hline Pre-test & Experiment & 0.06 & \multirow{2}{*}{ Homogen } \\
\hline & Control & 0.08 & \multirow{2}{*}{ Homogen } \\
\hline Post-test & Experiment & Control & 0.06 \\
\hline
\end{tabular}

The purpose of the homogeneity test is to determine whether or not the data is homogeneous. The researcher used the SPSS 26 program to determine whether or not the data was homogeneous. The variant of the group does not appear to be homogeneous if the significance level is less than 0.05. In contrast, if the significance level is greater than 0.05 , it indicates that the data group variant is homogeneous. The outputs indicated that the significances are 0.06 and 0.08 , which is quite significant. Essentially, it means that the variants of the two data sets from experimental groups were homogeneous, namely, the pre-test and the post-test. The Manova test was used to display the results of the hypothesis tests conducted before and after the test. After all is said and done, it is possible to conclude that the experimental and control groups have the same ability in terms of English language writing skills prior to treatment. There are statistically significant differences in English writing skills for each aspect of the study after treatment, i.e., in the experimental group with Integrated English learning using Moodle and in the control group with only face-to-face virtual learning. In other words, learning using Moodle media has a significant effect on English writing language skills in college students.

The result of the t-test was 3.17, which was higher than the result of the t-cv, according to the calculations (1.690). It demonstrates that the alternative hypothesis was 
accepted in hypothesis testing. In other words, the Blended Learning Model had a statistically significant impact on the writing achievement of the students. The experimental group (which made use of Moodle) received a higher overall score than the control group (using only face-to-face virtual class method). Following the findings of the previous study, blended learning outperformed traditional learning in all domains of the educational environment for clinical medicine students (Facharzt, Abos, Algaidi, Heissam, $\&$ Zolaly, 2013). Furthermore, when compared to the control group, which did not receive blended learning, the students' attitudes toward the use of blended learning were more positive (Alsalhi, Eltahir, \& Al-Qatawneh, 2019). According to another finding, the students were completely unanimous in their support for a specific type of blended learning that was implemented in the course, namely, a combination of theoretical study and practical skills to apply it, and the vast majority (96 percent) of the students were pleased with the blended format used for the course (Nazarenko, 2015). The use of Moodle, according to Escobar-Rodriguez and Monge-Lozano (2012), improves the learning-teaching process and results in students gaining better skills and grades.

The use of information and communications technology (ICT) in education, such as in this study, the use of ICT such as Moodle in the subject of "Article Writing for Journal", has become a necessity that cannot be put off any longer. Various information and communications technology (ICT) applications are available in the community and are ready to be used to their full potential for educational purposes. It can be carried out in a variety of ways depending on how it serves a purpose in education. The integration of information and communication technology (ICT) into the English language learning process is critical for fostering innovation and student motivation (Pavel, et al, 2015). The use of information and communication technology (ICT) in a subject called Integrated English was investigated in this study. Instead of traditional classroom instruction, Moodle-based learning was used in conjunction with the traditional classroom setting to deliver the course content.

The availability and ease of access to available teaching materials, exercises, and upto-date information regarding their course from effectively anywhere outside of the classroom, as well as the collection of all learning materials in one place, were the most promising things students mentioned. They also mentioned rapid feedback on the course website of their e-communications (through online chat sessions and exchange of E-mails) (Ahmad \& Al-Khanjari, 2011). In terms of language teaching, the implementation of blended learning has at the very least been shown to improve students' writing, spelling, and grammar skills, if not significantly (Adas \& Bakir, 2013). Furthermore, in this digital age, the use of technology in the classroom is a must because today's students cannot be separated from their technology and the use of mobile technology will assist students in becoming active learners who are prepared to study at any time and from any location (Muthalib, Abdelsatar, Salameh, \& Dalle, 2011).

\section{Conclusion}

A significant difference in writing achievement was found between students who were taught using a Blended Learning Model using the LMS Moodle and those who were taught using the only face-to-face virtual class method, according to the results of this study's data analysis and findings. The researchers discovered that the value of the t-test was higher than the value of the t-cv $(3.17>1.690)$ after performing the calculations. Which is the Ho, and which are the Ha, were accepted and rejected. The use of the Blended Learning model in aggregation with Moodle had a statistically significant impact on the 
writing achievement of students in the "Article Writing for Journal" subject. The Blended Learning Model, on the other hand, has a statistically significant impact on students' writing achievement. The use of the Blended Learning Model had a positive impact on students' writing achievement, particularly in the form of news article text. The Blended Learning Model guided and motivated the students in their efforts to gather information and develop it into quality writing assignments.

This pilot study is a first step toward incorporating Moodle into the delivery of an English writing course called "Article Writing for Journal" for post-graduate students at STKIP PGRI Sidoarjo. It is far from perfect and there is room for improvement, for example, by providing more specific instruction and techniques for each skillset and by incorporating gamification and animation to increase students' engagement, among other things. This research also demonstrates that the adaptation of innovative technology, such as Moodle, can provide opportunities for the development of new methods and the improvement of teaching techniques that are more effective and efficient in the classroom. It is highly recommended that schools and other educational institutions maximize the use of information and communications technology (ICT), such as Moodle and other technologies, to educate students. However, the scope of this study is limited to the implementation of blended learning to improve students' writing skills in higher education. As a result, additional research to determine the effects of the blended learning model on other language skills should be carried out.

\section{References}

Ahmadi, D. M. (2018). The Use of Technology in English Language Learning: A Literature Review. International Journal Research English Education.

Ayuningsih, W. et al. (2020). Implementation of Islamic Education Curriculum Development in Al-Ulum Islamic School Medan. Budapest International Research and Critics in Linguistics and Education (BirLE) Journal. P. 1033-1044.

Brown, H. D. (2007). Teaching by Principles. New Jersey: Prentice Hall.

Brown, H. D. (2007). Teaching by principles: An interactive approach to language pedagogy (3rd Ed.). White Plains, New York: Pearson Education.

Cole, J. (2005). Using moodle: Teaching with the popular open source course management system. US: O'Reilly Media, Inc.

Costa, C., Alvelos, H., \& Teixeira, L. (2012). The use of Moodle e-learning platform: a study in a Portuguese University. Procedia Technology, 5, 334-343. doi:10.1016/j.protcy.2012.09.037

Eka, R. (2021). Effectiveness of Teaching English for Specific Purposes in LMS Moodle: Lecturers' Perspective. doi:https://doi.org/10.21462/jeltl.v6i1.498

Elhawwa, T. (2017). The Implementation of Moodle Platform through Lecturer's Perspectives at English Department journal on English as a Foreign Language, 7(2), 227-240. Retrieved from http://e-journal.iain-palangkaraya.ac.id/index.php/jefl

Kemdikbud. (2020). Surat Edaran Mendikbud No. 35952/MPK.A/HK/2020 tentang Pembelajaran secara Daring dan Bekerja dari Rumah dalam Rangka Pencegahan Penyebaran Corona Virus Disease (Covid-19). Jakarta, Indonesia.

Linse, C. T., \& Nunan, D. (2006). Practical English Language Teaching: Young Learners. New York: Mc. Graw-Hill.

Mirabolghasemi, Iahad, M. N., \& Qomaruddin, M. (2014). Evaluating students' learning experiences using course management system in a blended learning. International Conference on Electrical Engineering Computer Science and Informatics (EECSI). 
Muthalib, A. A., Abdelsatar, A., Salameh, M., \& Dalle, J. (2011). Making learning ubiquitous with mobile translator using Optical Character Recognition (OCR). . International Conference on Advanced Computer Science and Information Systems (pp. 233-236). Kuala Lumpur: IEEE.

Robb, T. (2004). Moodle: A virtual learning environment for the rest of us. TESL-EJ, 8(2), $1-8$.

Rukayah. (2014). the writing skill of 3th grade students of sibulue subdistrict junior high school of bone regency. International journal of linguistics, 6(2).

Sanjaya, W. (2011). Learning process which is oriented on educational process standard. Jakarta: Kencana.

Sharma, P., \& Barret, B. (2010). Blended learning: Using technology in a beyond the language classroom. Thailand: MacMillan Publishers Limited.

Shomali, Q. (2007). Blended learning: a seminar to ensure the quality of education and academic accreditation. Proceedings of Sixth Conference of the Deans of the Faculties of Arts in the Universities Members in the Association of Arab Universities. Jinan University.

$\mathrm{Wu}, \mathrm{W}$. (2008). The application of Moodle on an EFL collegiate writing environment. Journal of Education and Foreign Languages and Literature, 7(1), 45-56. 